\title{
To assess the knowledge and compliance on hand hygiene among staff nurses working in selected community health centers: descriptive cross- sectional research design
}

\begin{abstract}
A descriptive cross sectional research study undertaken to assess knowledge \& compliance of hand hygiene among staff nurses working in community health centers of selected district of Gujarat. Researcher recruited total 50 samples through nonprobability purposive sampling technique. Researcher introduced a validated research tool, which consist structured questionnaire to assess knowledge \& observation checklist to assess compliance on hand hygiene, here structured questionnaire consist 26 questions based on aspects of various techniques of hand hygiene \& checklist consists steps of hand washing \& 13 items on techniques of hand hygiene. The study finding reveals that $76 \%$ (38) staff nurses has average knowledge, $14 \%$ (7) has good knowledge \& $10 \%$ has poor knowledge, whereas $70 \%$ (35) staff nurses had average level of compliance, $22 \%$ (11) had good level of compliance \& $8 \%$ (4) had poor level of compliance regarding hand hygiene. It concludes that staff nurses need to review hand hygiene guideline in order to improve knowledge as well as compliance.
\end{abstract}

Keywords: knowledge, compliance, hand hygiene, staff nurses
Volume 5 Issue 6 - 2018

Anjali Bhatt,Anil Sharma

Manikaka Topawala Institute of Nursing, India

Correspondence: Anil Sharma,Associate Professor, Manikaka Topawala Institute of Nursing a constituent of Charotar University of Science \& Technology, Changa, Ta: Petlad, Dist. Anand, Gujarat-38842 I, India,

Email anilshavma.nur@charusat.ac.in

Received: May 04, 2017 | Published: November 21, 2018

\section{Introduction}

Hygiene is the practice of keeping oneself and one's surroundings clean, especially in order to prevent illness or the spread of disease. Hand washing for hand hygiene is the act of cleaning the hands with or without the use of water or another liquid, or with the use of soap, for the purpose of removing soil, dirt, and/or microorganisms. The Centers for Disease Control and Prevention (CDC) has stated, "It is well-documented that one of the most important measures for preventing the spread of pathogens is effective hand washing." The main medical purpose of washing hands is to cleanse the hands of pathogens and chemicals which can cause personal harm Or disease. ${ }^{1}$ Most healthcare-associated infections (HAI) are thought to be transmitted by the hands of Healthcare Providers (HCPs) through direct contact, mainly when the hands of HCPs transfer microorganisms between individuals or between individuals and the environmental reservoir. ${ }^{2}$

Hand hygiene is recognized as the leading measure to prevent cross-transmission of microorganisms and to reduce the incidence of health care associated infections. ${ }^{3}$ Despite the relative simplicity of this procedure; compliance with hand hygiene among health care providers is as low as $40 \%{ }^{3}$ One of efforts towards high compliance is the introduction of an evidence-based concept of "My five moments for hand hygiene" by World Health Organization. ${ }^{4}$ These five moments that call for the use of hand hygiene include the moment before touching a patient, before performing aseptic and clean procedures, after being at risk of exposure to body fluids, after touching a patient, and after touching patient surroundings. ${ }^{5}$

There are several published information on hand washing practices of Health Care Workers (HCWs), their knowledge, perceived barriers\& facilities for practicing hand washing in hospitals from India. ${ }^{6-10}$ Awareness rregarding hand washing and hygienic practices is low among doctors and nurses in India, according to a study by AIIMS and Lady Hardinge Medical College (LHMC) covered over 100 doctors and nurses from March 2015 to May 2015 which stressed on regular training sessions to ward off the threat of infections. ${ }^{7}$ It was found that most of the doctors still believe that soap and water is the best way of ensuring hygiene of the hand even though the World Health Organization (WHO) recommends alcohol-based hand rub (ABHR) for hand antisepsis as it is acts fast and has broad spectrum of antimicrobial activity. ${ }^{11}$

Compliance by healthcare workers with recommended hand hygiene procedures has remained unacceptable, with compliance rates generally below $50 \%$ of hand hygiene opportunities. Many factors have contributed to poor hand washing compliance among healthcare workers, including lack of knowledge among personnel about the importance of hand hygiene in reducing the spread of infection and how hands become contaminated, lack of understanding of correct hand hygiene technique, understaffing and overcrowding, poor access to hand washing facilities, irritant contact dermatitis associated with frequent exposure to soap and water, and lack of institutional commitment to good hand hygiene. ${ }^{12}$

Many studies have consistently shown that constantly use of hand hygiene has reduced nosocomial infections and cross contamination of multi resistant infection in hospitals (Mathai et al. 2011). Most of nosocomial infections are thought to be transmitted by the hands of Health Care Workers. So assess the knowledge, attitude and practice of hand washing among HCWs is important (Khaled et al. 2006) 
Hospital acquired infections poses a very real and serious threat to all who are admitted to hospital. Pathogens are readily transmitted though Health Care Workers hands, and hand hygiene practice substantially reduce the transmission. So study to assess HCWs hand hygiene practices is important (Creedon 2005). ${ }^{13}$

After going through these all literature \& being registered nurse, researchers identified that the main reason for nosocomial infection is poor hand hygiene. The efforts to minimize the onset and spread of infection are the responsibility of the nurse. Nurses working in hospitals must be knowledgeable about hand washing guidelines and must follow the same to protect the patient from infection. Considering the importance of hand hygiene in nursing care, Investigators motivated to take up the study.

\section{Material and methods}

This study conducted with quantitative research approach with descriptive cross-sectional research design. This study planning with following objective:

i. To assess the knowledge on Hand Hygiene among staff nurses.

ii. To assess the compliance of Hand Hygiene among staff nurses.

iii. To find out association between knowledge regarding Hand Hygiene among staff nurses with selected Socio-demographic variables.

iv. To find out association between Compliance on Hand Hygiene among staff nurses with selected Socio-demographic variables.

Research Approach: Quantitative Research Approach

Research Design: Descriptive cross-sectional research design

Participants: According to sampling criteria including inclusion \& Exclusion criteria staff nurses working in selected community health centers of selected district of Gujarat. Formal permission and ethical clearance received from competent authorities. And consent letter get signed by each participant.

Measures: The final research tool developed by researcher and it consist three sections, which are

Section I: Information on socio-demographic variable of respondents containing six items.

Section II: This section sought information to assess the knowledge on Hand Hygiene.

For this structured knowledge questionnaires containing 26 questions regarding Hand Hygiene is used. This section includes questions based on aspect of various techniques of Hand Hygiene including medical hand washing, surgical hand washing, alcohol based hand rub how, when and where it used. It also includes questions regarding infection and flora (hospital acquired, droplet, transient and residential flora).

Section III: Information on compliance regarding Hand Hygiene by the use of observation checklist containing 7 steps of medical hand washing, 13 other questions on other techniques of Hand Hygiene (including surgical hand washing and alcohol based hand rub).

Sample: Total 50 samples of staff nurse working in community health centers were selected by purposive sampling technique.

Methods: After receiving formal permissions from respective institutions or hospitals, the researchers introduced research tool for data collection. Samples confidentiality maintained. After data collection the score interpreted according to the tools.

Findings: The obtained data were entered in to a master sheet for tabulation, analysis and interpretation, using descriptive and inferential statistics. The data collected are presented under the following headings. Findings related to Socio-Demographic Variables. Findings related to Knowledge of staff Nurses regarding Hand hygiene working in Community Health Centers. Findings related to compliance of Hand Hygiene among Staff Nurses working in Community Health Centers. Findings related to association between Knowledge regarding Hand Hygiene with selected Socio-Demographic Variables of participants. Findings related to association between Compliance regarding Hand Hygiene with selected Socio-Demographic Variables of participants (Tables 1-5)

Table I Frequency and percentage distribution of staff nurses according to Socio-Demographic Variables. $\mathrm{n}=50$

\begin{tabular}{|c|c|c|c|}
\hline S.no & Socio-demographic variables & Frequency & Percentage \\
\hline \multirow[t]{3}{*}{ I } & Gender & & \\
\hline & Male & 11 & $22 \%$ \\
\hline & Female & 39 & $78 \%$ \\
\hline \multirow[t]{5}{*}{2} & Age & & \\
\hline & $<20$ years & 0 & 0 \\
\hline & $21-30$ years & 23 & $46 \%$ \\
\hline & $31-40$ years & 17 & $34 \%$ \\
\hline & $>40$ years & 10 & $20 \%$ \\
\hline \multirow[t]{5}{*}{3} & Education & & \\
\hline & ANM & 6 & $12 \%$ \\
\hline & GNM & 34 & $68 \%$ \\
\hline & B.Sc Nursing & 10 & $20 \%$ \\
\hline & M.sc. Nursing & 0 & $0 \%$ \\
\hline \multirow[t]{5}{*}{4} & Job Experience & & \\
\hline & 0 to 5 years & 18 & $36 \%$ \\
\hline & 5 to 10 years & 10 & $20 \%$ \\
\hline & 11 to 15 years & 8 & $16 \%$ \\
\hline & $>15$ years & 14 & $28 \%$ \\
\hline \multirow[t]{3}{*}{5} & HHTraining & & \\
\hline & Yes & 3 & $6 \%$ \\
\hline & No & 47 & $94 \%$ \\
\hline
\end{tabular}

Table 2 Frequency distribution of knowledge scores of staff nurses regarding Hand Hygiene. $n=50$

Level of knowledge score range frequency percentage (\%)

$\begin{array}{lccc}\text { Adequate } & 23-26 & 7 & 14 \% \\ \text { Average } & 19-22 & 38 & 76 \% \\ \text { Poor } & 0-18 & 5 & 10 \%\end{array}$


Table 3 Frequency distribution of compliance scores of staff nurses regarding Hand Hygiene. $n=50$

\begin{tabular}{llll}
\hline \multicolumn{4}{l}{ Level of knowledge Score range Frequency Percentage (\%) } \\
\hline Adequate & $17-20$ & 11 & $22 \%$ \\
Average & $14-16$ & 35 & $70 \%$ \\
Poor & $0-13$ & 4 & $8 \%$ \\
\hline
\end{tabular}

Table 4 Association between the Knowledge of staff nurses on hand hygiene with selected demographical variables $n=50$

\begin{tabular}{|c|c|c|c|c|c|c|}
\hline \multirow{2}{*}{$\begin{array}{l}\text { Socio-demographic } \\
\text { variables }\end{array}$} & \multicolumn{3}{|c|}{ Knowledge score } & \multicolumn{2}{|l|}{$\mathrm{CHI}$ square } & \multirow{2}{*}{ DF } \\
\hline & Good & Average & poor & Calculated & Tabulated & \\
\hline Gender & & & & \multicolumn{3}{|l|}{ (NS) } \\
\hline Male & 1 & 9 & 1 & \multirow{2}{*}{0.317227} & \multirow{2}{*}{5.99} & \multirow{2}{*}{2} \\
\hline Female & 6 & 29 & 4 & & & \\
\hline Age & & & & \multicolumn{2}{|l|}{ (NS) } & \\
\hline$<20$ Years & 0 & 0 & 0 & 3.415345 & 12.59 & 6 \\
\hline Education & & & & \multicolumn{3}{|l|}{ (NS) } \\
\hline ANM & 1 & 4 & 1 & & & \\
\hline GNM & 1 & 18 & 4 & \multirow{3}{*}{14.89269} & \multirow{3}{*}{12.59} & \multirow{3}{*}{6} \\
\hline B.Sc Nursing & 5 & 16 & 0 & & & \\
\hline M.sc. Nursing & 0 & 0 & 0 & & & \\
\hline Job Experience & & & & \multirow{2}{*}{\multicolumn{2}{|c|}{ (NS) }} & \\
\hline 0 to 5 Years & 2 & 13 & 3 & & & \\
\hline 5 to 10 Years & 3 & 6 & 1 & \multirow{3}{*}{5.29937} & \multirow{3}{*}{12.59} & \multirow{3}{*}{6} \\
\hline 11 to 15 Years & 1 & 7 & 1 & & & \\
\hline$>15$ years & 1 & 12 & 0 & & & \\
\hline $\mathrm{HH}$ training & & & & \multicolumn{2}{|l|}{ (NS) } & \\
\hline Yes & 0 & 3 & 0 & \multirow{2}{*}{1.007839} & \multirow{2}{*}{5.99} & \multirow{2}{*}{2} \\
\hline No & 7 & 35 & 5 & & & \\
\hline
\end{tabular}

Table 5 Association between the Compliance of staff nurses on hand hygiene with selected demographical variables $n=50$

\begin{tabular}{|c|c|c|c|c|c|c|}
\hline \multirow{2}{*}{$\begin{array}{l}\text { Socio-demographic } \\
\text { variables }\end{array}$} & \multicolumn{3}{|c|}{ Compliance score } & \multicolumn{2}{|l|}{$\mathrm{CHI}$ square } & \multirow{2}{*}{ DF } \\
\hline & Adequate & Average & Inadequate & Calculated & Tabulated & \\
\hline Gender & & & & (NS) & & \\
\hline Male & 2 & 7 & 2 & & & \\
\hline Female & 9 & 28 & 2 & 2.0025429 & 3.99 & 2 \\
\hline Age & & & & (NS) & & \\
\hline$<20$ Years & 0 & 0 & 0 & & & \\
\hline $21-30$ Years & 6 & 15 & 2 & 5004090 & 1250 & 6 \\
\hline $31-40$ Years & 3 & 14 & 0 & 3.0840701 & 12.39 & 6 \\
\hline$>40$ Years & 2 & 6 & 2 & & & \\
\hline Education & & & & (NS) & & \\
\hline ANM & 2 & 2 & 2 & & & \\
\hline GNM & 6 & 26 & 2 & 32838254 & 1259 & 6 \\
\hline B.Sc Nursing & 3 & 7 & 0 & 3.20302034 & 12.57 & 0 \\
\hline M.sc. Nursing & 0 & 0 & 0 & & & \\
\hline
\end{tabular}


Table Continued

\begin{tabular}{|c|c|c|c|c|c|c|}
\hline \multirow{2}{*}{$\begin{array}{l}\text { Socio-demographic } \\
\text { variables }\end{array}$} & \multicolumn{3}{|c|}{ Compliance score } & \multicolumn{2}{|l|}{$\mathrm{CHI}$ square } & \multirow{2}{*}{ DF } \\
\hline & Adequate & Average & Inadequate & Calculated & Tabulated & \\
\hline Job Experience & & & & (NS) & & \\
\hline 0 to 5 Years & 4 & 12 & 2 & & & \\
\hline 5 to 10 Years & 1 & 9 & 0 & & & \\
\hline II to 15 Years & 2 & 6 & 0 & 4.270872 & 12.59 & 6 \\
\hline$>15$ Years & 4 & 8 & 2 & & & \\
\hline
\end{tabular}

\section{Conclusion}

In the present study researcher found that majority of staff nurses $38(76 \%)$ had average knowledge regarding Hand Hygiene, while $7(14 \%)$ had good knowledge and $5(10 \%)$ had poor knowledge. The mean score was 20.7. Researcher also observed the level of compliance among staff nurses. In this majority of staff nurses $35(70 \%)$ had average level of compliance, while $11(22 \%)$ of staff nurses had good level of compliance and $4(8 \%)$ of staff nurses had poor level of compliance regarding Hand Hygiene. The mean score was 15.66. And all significant values kept on level of .05\%.

\section{Acknowledgements}

I would like to acknowledge nursing division and Medical officers of all community Health Centers.

\section{Conflicts of interest}

Author declares that there is none of conflicts.

\section{References}

1. Pittet D, Hugonnet S, Harbarth S, et al. Effectiveness of a hospitalwide programme to improve compliance with hand hygiene. Infection control Programme. Lancet. 2000;356(9238):1307-1312.

2. Albert RK, Condie F. Hand washing pattern in medical intensive care units. N Engld Med. 1981;304(24):1465-1466.

3. Boyce JM, Pittet D. Guideline for hand hygiene in health-care settings. Recommendations of the healthcare infection control practices advisory committee and the HIC-PAC/SHEA/APIC/IDSA hand hygiene task force. Morbidity and Mortality Weekly Report. 2002;51(RR-16):1-45.
4. Longtin $Y$, Sax H, Allegranzi B, et al. Videos in clinical medicine. Hand hygiene. The New England Journal of Medicine. 2011;364:e24.

5. Basurrah M, Madani T. Hand washing and gloving practice among health care workers in medical and surgical wards in a tertiary care centre in Riyadh, Saudi Arabia. Scandinavian Journal of Infectious Diseases. 2006;38(8):620-624

6. Ansari SK, Gupta P, Jais M, et al. Assessment of the Knowledge, Attitude and Practices Regarding Hand Hygiene amongst Healthcare Workers in a Tertiary Health Care Centre. International Journal of Pharma Research and Health Sciences. 2015;3(3):720-726.

7. UNICEF India. Health News. Global Hand washing Day. 2008.

8. Mehta Y, Chakravarthy M, Nair R, et al. Prospective study to evaluate hand washing compliance in two Indian Hospitals. Am J infeciont control. 2005;33:e73-e74.

9. Mahesh Devnani, Rajiv Kumar, Rakesh KS, et al. A survey of handwashing facilities in the outpatient department of a tertiary care teaching hospital in India. J Infect Dev Ctries. 2011;5(2):114-118.

10. Das D, Mandal AK, Das J, et al. Practice of Personal Hygiene \& Morbidity Pattern among Medical Students of a Rural Medical College, West Bengal, India. IOSR Journal of Dental and Medical Sciences. 2015;14(5):39-44.

11. Daniels IR, Rees BI. Hand washing: simple, but effective. Ann R Coll Surg Engl. 1999;81(2):117-118.

12. Girou E, Chai SHT, Oppein F, et al. Misuse of gloves: the foundation for poor compliance with hand hygiene and potential for microbial transmission? Journal of Hospital Infection. 2004;57(2):162-169.

13. Hugonnet S, Perneger TR, Pittet D. Alcohol-based hand rub improves Compliance with hand hygiene in intensive care units. Arch Intern Med. 2002;162(9):1037-1043. 